\title{
De-Mythologisation - path towards the Hidden Truth in Albanian Modern Drama
}

\author{
Erenestina Halili
}

University of Tirana, Albania

Email: erenestina@gmail.com

\section{Doi:10.5901/ajis.2013.v2n2p509}

\begin{abstract}
When we look at the modern drama Albanian in developed in Kosovo and its most significant works that have used the IllyrianAlbanian mythological heritage, the Bible, the biblical -- cannon and other mythological constructs, that derives mainly from the Albanian folklore, or today's believes etc., it can easily be noted that apart from its aspect of having it used as a subject or "a story", or as a way of believing, or as a collective psychosis, it (the drama) has also used in a rational way the myths, which are products of the collective social consciousness, thus are part of the mythological mechanism of today's society.
\end{abstract}

Keywords: drama, Albania, Kosovo, folklore, mythology, heritage

\section{Introduction}

Although the today's society is dominated by the deep and continues processes of knowledge of the existence of the world, the sophistication of the relations between the thinking and acting becomes increasingly larger. This sophistication comes from the unaccountably irrational processes, from the unaccountably of many human inside and outside phenomena (which often put him on inferiority, fear, uncertainty, experience thrilling, mystery). Thus, the mythological structures are used by the playwrights as provoking emotional elements, as opportunities to create situations and conditions of pursuing moody sensory nature, fantasy harassment, capture of attention in surprise, causing fear, empathy, delirium, increased level of hypnosis, illusion, magic, effects (these always taken from the esthetic perception).

Overcoming of what is reasonable, rational, harmonious, clearness, logic through irrational, instinctive, mental disturbance, unfounded, chaotic, is realized in many modern dramas precisely through the mythological process, which involves the understating of the subject, is then extends to the way the events are presented, to achieve then the structure of the characters thinking and then the ways in which the message is transmitted to the perceiver/reader. As is known, myths (from Ancient Greek Mythos - "words, speech, conversation, story, teaching, legend etc.") have been and remain on human stories about the peoples activities during pre-civilization times that are intertwined with the presence of various gods in accordance with different times and various places, where miraculous happenings are intertwined, in many occasions, with the human heroic feats. While the term "mythology" comes from the union of the old Greek word "mythos" and "logos" (doctrine, words), which is used at least in three meanings: 1) as a science or theory that examines the myths, 2) as a set of myths of people, 3) as a specific spiritual creativity that processes myths. Within the structure of a myth coexist and interact simultaneously faith and religion, knowledge and history, synthesis and philosophy, art and esthetics. Myth is the truth and lies at the same time, knowledge and ignorance, reality and illusion.

As genuine spiritual structure of different peoples, in different time and space, myths appear as recognized stages of social development in two basic meanings: a) as transcended realities that existed as well as religion, faith and b) as made up realities, where fantasy, fiction, and creation turns them into phenomenon, which have strong impacts on the processing of human social conscience.

In his books "Mythology, folklore, literature" and "Metatheoretical Esthetics. Classics or Neo-classic?" the esthetic Alfred Uçi explains that the mythological creativity by its diffusive and mutual nature takes considers subject and object as being equal without differentiating one from the other, hence the marked sign. Meanwhile, the myth has as its own feature the internal enlightenment and hypnotic character. Death and life, the alive or the dead are placed in the same reality. This means that the myth does not give the figures as symbols, metaphors, signs, but as something real, something that coexists and interacts with people, thus as tangible reality in which the phrase appears inseparable from what is expresses. Of course, the drama that has become the subject of myths characters or subjects or mythical figure is not 
equivalent to the myth in terms of experiencing and cohabitation between the creature and the dead, between the real and phantasmagoric. The problem here is to present the issue how much the mythical matter is transformed into dramatic literature matter. We will only talk about this aspect into our analysis regarding various dramas that have being chosen. It should also be emphasized another very specific and identifiable aspect, where the drama naturally tends towards the myth: the mythological thinking mainly operates with concrete sensory impressions. Early man used to consider the creatures of his imagination and beliefs as weird creatures, with mysterious power that hustle and bustle with him by expressing different types of feelings, extraterrestrial and superpower powers, sudden impact, which cannot be perceived by senses and underdeveloped minds. Even the characters in the Albanian dramas of mythical subjects are in the role of early human mythic man. But, an essential thing changes: the recipient. Today's reader can never be identified with the action of the mythical character, or with the ways the early recipient perceived (perception with strong religious elements). Rather, he distances from there from the logical action of the reason and the scientific knowledge.

It is known that mythological thought, as a rule, is accompanied by emotional and affective experiences. This is because the heroic feats and tragic fatalities that are told in myths are extraordinary, filled with horror, fear, surprise, intense events and extreme situations that overwhelm the consciousness of the person who perceive. Being located on the Balkan Peninsula, with no less active connections and communications with countries of the Mediterranean realms, certainly to many Albanians rites, myths, beliefs, in some elements have affinities with rituals, myths, Thracian-Illyrian beliefs, with Greek beliefs a bit away, which is an evidence of a fellowship of their appearance.

Kosovo Albanian playwrights have used the mythological material in favor of attractive dramatic subjects, in order to create characters with great expressive force. This path that has been followed has been in favor of the creating such psychological conditions that show deep emotions, in favor of decoding from which from the early semantics of the myth is moved to the universal ideological-philosophical parallels that bear the essence of the being itself. Such an approach, as assumed, increases significantly the impact on the reader, which is part of understanding and feeling of this mythological subject, either from their own personal experiences, whether from community experiences, ethnic, national. From the most obvious approaches in the field of use of mythological matter of Albanian modern and postmodern drama in Kosovo, religious ethnology is widely used by some writers as B. Musliu, R. Qosja, Teki Dervishi, Mehmet Kraja. (The structure of drama, especially in the experiences of the characters, their mentality found in many religions, cults, rituals and numerous myths associated with this category precisely are met.)

\section{From mythology to drama}

The arsenal of myths used by Kosovo Albanian drama comes from four main sources:

1) From the ancient primitive mythology of different peoples from various pre-civilized periods, mainly the Neolithic period, and that are then absorbed and circulated in different countries and peoples with wide impact on social consciousness of different historical periods, religion, philosophy, morals, art, etc.

2) From the classical Greek and Roman mythology, with no less elements of reproduction of the earliest myths and the presence of new myths.

3) From the monotheistic religions mythology, mainly from the Bible and the Qur'an, but also from books and other "holies", where stories about creation, God, prophets, etc., where there is a genuine form of myth, strongly mixed with beliefs, theological doctrines, rites, etc.

4) From the mythological arsenal of our times, even those resources, which, for its structure, have affinities with the way the myths are established and operate.

What relates to the Kosovo Albanian drama and our argument is that the myth in various dramatic works by the Albanian authors, is always placed in a balance of revaluation process of recognition and knowledge, which cause it to change function: for example, faith and religion are seen and become .....

In his book "The Birth of Greek tragedy" Publishing House "Eugen, Tirana 2001, the distinguished philosopher Friedrich Nietzsche, considered as the basic structure of Greek tragedy two essential origins: the Dionysian origin and the Apollonian origin. Myth as the source of subjects emerges as a cause and consequence of action of heroes, gods and others. Its structure was syncretism: reality and religion.

Friedrich Nietzsche noted that the Gods, as part of the implementation of religion, had several functions: a) the punishment of offenders, b) granting of the right, c) salvation from disaster, death, and disease of kings, princes and heroes. Sacral sentences of Gods are represented directly from them in the form of prayers and worships, as messianic 
message, as a philosophy of life, as a moral stand and legal right, as they are shown charitable figures in the stage action exercising the right to award or take privileges or benefits (beneficent). Recognition of the Gods and giving by them of the [didaskalive] to the tragic characters was done at the end of the tragedy, when they, came down to the stage by a crane which was placed in front of heroes. This solution was called Deus ex machine - God from the machine. This direct testify the religious character of the act of reception by the general public, which he took as the "truth" (through illusion and hypnotic effect). This also explains why the ancient Greeks collectively participate in major festivities of Dionysius where tragedies were played, because the show was at the same time an artistic aesthetic act and a religious act. Even catharsis was two-sided, aesthetic and religious, as a spectator and as a believer; an artistic source or a given information and argument in order to explain the historical processes of civilization periods early or late.

This is the reason why the myths in different dramas "rot", which means that that is the reality lose value on the ability of readers to scientifically explain "why" in the birth of their psychosocial and mechanism of the birth. However, human society today, despite tremendous technological development, yet produces new myths. Mite such myths are created as a result of ongoing processes of social development. Such observations are present in dramas of Mehmet Kraja, Haqif Mulliqi, Neziraj Lives, Shkëlzen Krasniqi, Azem Shkrel, Rasool Shabani etc. There are also further myths that are genuinely innovative of the nature of literary artistic creativity to invent imaginary realities, surreal, with concentrations in order phenomena pertaining to a possible future or imagined.

Myths of Albanian modern playwrights, but also "realistic", traditional, are considered by different angles: as part of religion, as part of the early polytheistic mythology, as esoteric phenomenon, as its transfiguration in the Albanian folklore. As compared with optics pluralistic in his assessment studies today, according to Alfred Uçit, different scholars "equate myth with religion, others equate with philosophy, there is one myth that consider myth as a pure artistic aesthetic phenomenon, while others tie the essence of the myths with a quite irrational and illogical origin, while others perceive it as the foundation of any underlying mental structure, logic, science and of any intellectual reasoning." But, the research we have done to the Albanian drama in Kosovo, rarely if ever, turns out to be a myth conceived as syncretic structure, which implies the presence and the interoperable coexistence of religion and philosophy, the morality of art, scientific knowledge of esoteric phenomena etc. However, it is taken only in the values of creating a new artistic aesthetic reality, with genuinely literary functions, and used sometimes as a metaphor and as an element with synthesis and universal force, sometimes as emotional situation, sometimes as allegory, once as a ritual, effect and many times as a concrete literary figure. As we take under consideration, dramas such as "Coast of grief", "a reprise of freedom", "the man with zymrydi eyes", "public dinner" of Teki Dervish, "Rrakullima" and "The Sourer of Rooster Inn" of Bekir Musliu, " GOF "Anton Pashku," Beselam, why sacrifice", "Gala", "living Sfinga" of Recep Qosja, "paper moon" Mehmet Kraja,"Hijesina" of Islam Nabi,"Me and God" and Ekrem Kryeziu etc., the aesthetic and critical analysis distinguish the use of myths and mythological material on various traits, despite the fact that the authors have used the diffusive and operational character between the subject and the object, what is believed and what is not believed, on the other hand, they have conceived it functions always in the artistic and illusionist conventions, therefore decomposing the direct mythical reality and taking it as true but not as implication, drift, so as an artistic expression possibility. By utilizing the awesome power that the overall sensory mythological content in these dramas gives, the authors provide opportunities for imaginative recreations realities and phantasmagoric, by creating human strangers or unreal environments, which cause emotional affective reactions. In turn, these emotions significantly increase the degree of affective experiencing of dramatic work by the reader.

Meanwhile, this mythological subject is taken by these authors in other contents. Here I would like to mention their natural attempt to create fictional realities, illusory, non-existent, to devise or create another reality: the reality "dreamer". Within this reality the abovementioned playwrights have insisted also on creating expected or anxious situations in detecting suppressed desires or aspirations that are expected to occur (to a character or a group of personages). Of course, these are conceived as an essential part of modern or postmodern typology of dramas in order to expand the hypnotic effect to the reader, as increased artistic expressiveness. For example, although the [tetraptikun] of the "The Sourer of Rooster Inn " of Bekir Musliu, a virtual and factious reality is created, why not a dreamer reality, in contrary, the content of the saga of Halil Garris is seen in the first holiness characteristic of the myth, specifically in the case of related saga of the oath and given word. Nine of witchcraft trials and hearings conducted by the spiritual sourer from the Rooster Hani discover even better the inside of this mythological tetralogy, which was taken as the subject of a criminal case. "What are you doing my lord? - He says. - All things, as it seems, start with me and from me ... Here I want to awake ballads ... From them I have to suck a charm that always seems to be cold ... Black ... Oh my Lord, help me to draw at least the Garris Hali's face and then let's start to hollow out the plague in my face ... " 
By camouflaging the author own voice through the voice of the Sourer of Rooster Inn, Bekir Musliu explains indirectly the purpose or, expressed in a more direct way, the access to material that is the subject of mythological drama: "the Anger of the artistic body also reaches the highest point - explains he in the [didaskalitë] of the drama - thus two scenes are faced into two categories of the meaning of myth and legend Halil Garris from its inception to its modernization of the visual and transformation in terms of the requirements of this theatres' game which, obviously, is the Sourer of Rooster Inn. Mythology is closely related to the rite and ritual. In his work "Tales of identity", the theorist and the representative of the critic mythical-symbolist literature Northop Fray argues the presence of archetypes in the works of different authors in different periods that provide recycling invariant unlikely literary character of a class or ways for the perception of dramatic situations. Since the rite, according to him, is a sequence of temporary acts with a certain sense, contrary, is exactly the myth that transforms into an archetypal rite of human behavior and attitude towards this or that object with which it comes into interactive relationships. Myth comes sometimes as an original way of telling the dramatic work, mainly in the structuring of the subject, while the rite and the archetype help in exposing the significance of this story. Hence, beyond the concrete analysis of the plays, we come to the view that favorite characters in modern Albanian drama of Kosovo authors, there are the heroes of the Albanian cultural anthropology calendar that often come out of the early tales and legends, the "Epic of the heroes ", without excluding, of course, other human figures that constitute the biblical and Koranic myths.

Albanian and non-Albanian mythology in the modern Albanian drama, with the rituals and beliefs that it has used, with different figures that it has collected from the popular mentality, from the psychology on how highly most of the psychosocial phenomena are considered and evaluated, has served not only to increase the level of emotions of the works, not just the power of suggestion or surprise, but also an original and contemporary way of presenting the relationship between the individual and the group of people, between the common conscience and sublimed reason, between the reality and the illusion, dream and the non-dream, between the utopia and the truth.

If we refer to the argument in the drama "Paper Moon" of Mehmet Kraja, these balances are good and clearly stated. The drama did not point out directly to a myth, nor is based on any story, legend or ritual ethnological concrete from the Albanian tradition. It is a myth originating from biblical scripture of Old Testament and it confront the God and the Devil into the human genesis, the episode of Eden with Adam, Eve and the serpent-devil, as it can be taken as a pattern of human settlement archetypal between God and Satan: which should chose and the temptation whom to avoid. So the drama has a character called Mephitis (Mephistopheles, otherwise the Devil Satan) and another character called Maestro (generally means man, especially Kosovo-Man). A pillar placed between man and where he will be gripped, is a reminiscent of Jesus Calvary, a biblical metaphor of crucifixion.

And so, as PROCEDIA, the drama is developed as a challenge of Mephitis to the Human, where the latter wins over the violence used on him, and even joke with the powerful, make fun of invading Mephitis as invader and violator of the Kosovo Man. Against here, of course, we does not have a direct form of biblical myth of the genesis or retelling of old Albanian and European legends or stories, which the man and the devil are found, Mephitis (remember, the legend of Doctor Faustus, from which Goethe got inspired and created his masterpiece "Faust").

Quite the opposite, the biblical myth and ancient European legend is presented only as a form of schematised, as a literary paradigm, as a strand. It is reconsidered and re-lifted by a scheme and a strand in a new way of appearance being turned into something completely different as regards the subject and original literary structure, where the characters not only are metaphors, but are also symbolized.

Despite their archetypal nature is preserved, they are adapted and reorganized matching an "another" reality, the conflict: Serb-conquering Kosovo. At "the Moon", the playwright also exceeds the meaning of its known mythological significance of her. Although in the mythology it is identified as "daughter" of the Earth, as the "girlfriend" of the Sun and many other definitions, among which stands out the its extraordinary beauty, the pale light, the loud and captivating power it has, contrary in the drama it that gets a more symbolic value and is placed in contradictory functions with its mythological origins. So, it is no longer a moon of "beautiful", "stunning", "poetic", "lyrical", "miraculous" etc., but an ugly, nasty, hideous, lying, even tragic moon. Why? Because for now its meaning is inverted, is transformed. Turn into a pure symbol, moon now appears as "made of paper", meaning being artificial. Further, it means the promising Europe, but often indifferent, that looks from far away the tragedy of the people of Kosovo and the Serb genocide. Beautiful words for Freedom, Rights of Peoples, and criticism towards Nationalistic Violence that sometimes articulated with witty and ironic tones, attribute contrasting qualities to the mythological symbol of the moon, and turn it into a symbol of indifference and unfulfilled promises. Thus, the case takes another function and mythical brand, meaningfulness. In such cases, reader 
distinguishes especially in drama "the secondary images, which bring cohesion historical values (of Albanians according to the EH drama) to the present day, through a conceptual and emotional depth.

Regarding the catharses and provocative effect of the myth to contemporary readers, prominent director of the twentieth century, Jerzy Grotowski (1969) in his famous book "For a poor theatre", explains: "In the first place, it would be a good thing to counterview the myth and not identify with.

In other words, while maintaining individual experiences, we can try to embody the myth, to wear his uncomfortable clothes, enabling thus the perception in the light of contemporary experience, the relativity of our problems, their relationship with "roots" and the relativity of "roots" itself. If the situation is brutal, if we lose ourselves naked, exposing and touching the most intimate psychic layers, masks of everyday life itself cracks and falls.

Secondly, even though we have lost "the mutual sky" of trust and unbreakable barriers that surround us, we are left with perceptual ability of the human organism. Only myth, embodied in tangible reality of the actor, in his living organism, can function as taboo. Rape of a living, exposure led to an excess cruel, restores us to a concrete mythical situation in a common experience of human truths.

Only in relation to this broad and complex significance as defined by the literal meaning and its under tones, the dramatic situation and the progress of action, from the symbols and the actions of the characters, the reader can turn to himself, to his time to reflect on these two together. In this way the symbol is seen as myth and metaphor as any other ethno-cultural and universal substratum." According to the researcher Mark Tirta, the unitary character of the ethnic Albanian mythology faces many directions. It is experienced in places of objects of cults of nature, the cult of family life and the "tribal". Is widespread, for example, the cult of the serpent (remember the drama of A. Shkreli "snake house" where mythical figure of the snake is a sign of prosperity and protection of the guest house, but on the other hand, thanks to the semantic transformations that the writer makes, it is immediately returned to a human-snake metaphor, that stings and poisons the lives of honest and ethical man). In some cult the drama of the mother is, or the cult of the breasts of women. A number of rituals are used by playwrights as a show of the Albanian identification with the nature, social organization, that of the tribal community, expressed through the name of inherited beliefs, the cult of the dead and death in general, in celebration of agricultural and livestock, the cult of the peaks (drama "GOF" Anton Pashku with the pinnacle of the Haut Mountains, that symbolizes the upper part, immaculate, and the noble identity of the Fatherland, the Nation, awareness).

In other dramas, additional rites, ritual as the scarecrow for a rain to save the crops, or fire rituals, ritual of foot around the house when the verge is violated, or the dragon mythology, dragons, fairy tales, holy Shepherd, verge mother, the time, motherhood, hob, rites and crafts, etc. cult numbers are brought. The wealth of rites, myths and beliefs, even if time "mythological" is locked, appears as a fragment socio-physiological and anthropological, which still lives and transmitted from generation to generation.

\section{Conclusions}

Beliefs, rituals, myths, either in its archaic forms or remodeled forms, are part of the family functioning, which should be referred to the birth rites, beliefs and myths about fate, happiness and disasters, pictures, and superstitions, reminiscent associated with death and the body of the dead, the interaction between the life-death-after death. Dissemination of the Albanian mythology with figures such as the dragon, witch, time, the mother of verge, and others related to the soil fertility, abundance of crops, farming, vineyards, orchards, livestock, removal of disasters and evil forces, are also prevalent and popular devotions such as those on the Day of Summer, Day of Vangjelizmoit, or Nowruz Day of or Our Lady Day, St. George, St. John's St. starch, etc.. All these and more are indicative of real and mythical ethno-folkloric among Albanians. Their rudimentary forms can be found in the way they are respected even today not only in the rural communities, but also in civil, customary and common structures that can be found in their roots deep into the centuries. Of course, this entire clause of myths, rituals, beliefs, tales, legends, etc. has turned itself into a source of subjects, human relationships, artistic images, and likely has enough artistic chances and expressiveness in many of the modern Albanian dramas in Kosovo.

\section{References}

Alfred Uci, (2008) Classics or Neoclassic? Metateorike esthetics of art, the Albanian Academy of Sciences, vol. II, Tirana, 2008, p. 424. 22 "for a poor theatre", Metropolitan theatre, AAB Rinvest, Tirana, 2010, f. 20.) 
Alfred Uci, (2008), Mythology, folklore, literature, publishing House "Naim", Tirana, 1982, pgs 22-29: Alfred Uci, (2008), Metateorike aesthetics of art. Classics or Non-classic? Academy of Sciences of Albania, Volume I, Tirana, Pg.426-429. 23

Bekir Musliu (1990) Northop Frye, Anatomy of criticism, Pristina, p. 34-69. 26

Bekir Musliu(1989) "The Sourer of Rooster Inn ", Renaissance, Pristina, p. 9.

Jerzi Grotowski, (1969) For a poor theatre, Simon and Shuster, New York,

Stefan Capaliku (2003) Modern aesthetic, GVG Ombre, Aesthetic Library, Tirana, 2003, p. 188-189. 